\title{
Integrated Knowledge Management in University of Darussalam Gontor: Building Learners' Character with Pesantren System
}

\author{
Imam Bahroni ${ }^{1}$, Abdul Hafidz Zaid ${ }^{2}$, Fairuz Subakir ${ }^{3}$, Alif Cahya Setiyadi ${ }^{4}$, Luthfi \\ Muhyiddin 5 \\ \{mas.bahroni@gmail.com¹, abuafadh@unida.gontor.ac.id², \\ alif.setiyadi@unida.gontor.ac.id ${ }^{4}$, luthfimuhyiddin@unida.gontor.ac.id ${ }^{5}$ \} \\ Universitas Darussalam Gontor, Indonesia ${ }^{12345}$
}

\begin{abstract}
Character education is the deliberate effort to develop a human character with positive behavioural qualities, ethical essence, and performance values for the sake of creating a meaningful life. This article explores and elucidates the importance of character buildings for the learners in the university level with the integrated university education system applied in the University of Darussalam Gontor. This field-research aims at describing and analyzing the character building in this university that primarily runs under the pesantren system. The findings from this study show that character building in this institution is an integral part of the formal, informal, and non-formal curriculum in which sciences, religious subjects, spirituality, and values of Gontor education are integrated. Furthermore, all of these curricular designs are taught with the character building methods of Gontor consisting of planning, organizing, motivating, controlling, and evaluating. Consequently, this system produces pious graduates with ten essential life competencies.
\end{abstract}

Keywords: Character, Character building, integrated system, Pesantren system.

\section{Introduction}

Character education according to Marshall, Caldwell, and Foster is perpetually believed, to some ways through which the students are being nurtured in the direction of seeing things in different perspectives; in other words, training them is always to exert maturity while challenging situations [1]. Another definition offered by Berkowitz and Hoppe is deliberate attempts to promote the development of student character in schools [2]. Here, character education includes all implicit and explicit educational activities that help young people develop specific personal strengths virtues. This character education is more than just a subject in classrooms, schools and other institutions. It has the ultimate aim on the development of good sense or practical wisdom which is the capacity to choose between alternatives intelligently. This capacity involves knowing how to choose the right course of action in stressful situations, and it arises gradually out of the experience of making choices and the growth of moral insight [3].

Character education is also the core effort to develop the ethical essence and performance values for young people in which family, social community, and schools are permanently included in this process. These education trilogies conceived assist young people to have the fundamental human life qualities such as faith, intellectual, moral, civic virtues, and 
comprehensive understand why it is essential to living with them not only to create right and excellence behaviour they need in the social life but also to develop them. All of these are necessary for human flourishing to attain the highest potential in life.

Educational institutions or school play fundamental roles as well as the rest two in determining every possible activity, approaches, methods, and strategies to build and develop character. The vast majority of institutions arrange and provide the character subject lesson extra-curricular activities as the way to improve student traits. They have two great primary goals: to help students become smart and to help them become good [4]. By this perspective, the essential purpose of character building is to draw up young people to head a flourishing life by teaching them acquisition and strengthening the virtues: the traits that sustain a well-rounded live and thriving society [3].

The cultivation of the character is the school responsibility where all of the aspects of the human development activities are required such as intellectual virtues, moral virtues, civic virtues, and performance virtues. The Intellectual virtue is character traits necessary for discernment, right action, and the pursuit of knowledge, truth, and understanding such as autonomy, critical thinking, curiosity, judgment, reasoning, reflection, and resourcefulness. Also, the moral virtues as the character traits that enable people to act well in situations that require an ethical response are manifested in compassion, courage, gratitude, honesty, humility, integrity justice, respect and other. Furthermore, to build people characters for engaging the civic's responsibility and contributing to the common good, civic virtues are needed for them such as citizenship, civility, community awareness, neighbourliness, service, and volunteering. Finally, those virtues are enabled by an instrumental value which is known as performance virtues (confidence, determination, motivation, perseverance, resilience, and teamwork) [3].

Having discussed on the pivotal role of the schools in developing student's character, we find that in fact, character and academic have the connection where the academic provides the student needs on moral character and performance character and helps them to develop both. The performance character and moral character with the eight strengths are the way to develop human potential ${ }^{1}$. Both moral and performance characters are the foundation for and a critical outcome of all academic and ethical endeavour. Hence, schools no longer need to talk about the balancing between academics and character education because of their occurrence simultaneously in mutually supportive ways [4].

\section{Gontor System of Character Education}

The essential characteristic of this pesantren consists of four main points. The first is the education and teaching is based on the teaching of Islam, which is the primary source is alQur'an and the Prophetic Tradition. The second is the whole student's activities are carried out in an integrated campus controlled by discipline within twenty-four hours under the personal direction of Kiai (spiritual leader). The third is that Kiai becomes the central figure of the student's characters and personality. The whole conduct an act, and deed of Kiai is the standard

${ }^{1}$. The eight strengths are (1) lifelong learner and critical thinker; (2) diligent and capable performer; (3) socially and emotionally skilled person; (4) ethical thinker; (5) respectful and responsible moral agent; (6) self-disciplined person who pursues a healthy lifestyle; (7) contributing community member and democratic citizen; and (8) spiritual person engaged in crafting a life of noble purpose (defined inclusively to encompass non-religious as well as religious world views and to focus on universally critical existential questions such as "What is the meaning of life?" and "What is authentic happiness?" 
of an excellent example to be imitated and practised. Moreover, the fourth point is the existence of the mosque as the centre of spiritual activities of students during day and night inside the campus.

\subsection{The spirit of Gontor Education}

The whole educational activities whether extra or co-curricular in this school is based on the values and the principle of education which is called as Panca Jiwa (the five basic principles), sincerity, simplicity, self-reliance, Islamic brotherhood and freedom.

a) The word sincerity can be defined as a quality of being sincere, which means that every individual in this school must try to be sincere in all acts of devotion for the sake of Allah (Ibadah) and not for gaining any profit from it. The teachers are sincere in doing the educational process, and the students are sincere in seeking knowledge. The implementation of this spirit is through the whole aspects of lives. Every school activity which can be seen, heard, and felt is considered as a mean of education.

b) The spirit of simplicity the other hand is meant as affirmative conduct towards every situation of life, and not surrender upon the problems of lives ${ }^{2}$ [5]. The precise meaning of it is to procure for the individual's values that will prepare them to face the trials and tribulations. It is to have strength, courage, determination, and self-control. Moreover, behind these all, lies nobility, bravery, and zeal never to give up, as well as the development of a strong mentality and character that are imperative and necessary in preparing them to face the hardship in life.

c) The spirit of self-reliance is defined as standing on one's feet. It is the most critical and useful ability provided by this school for its students. The students in this due regard practice by themselves how to be self-reliant in undertaking all his daily necessity, up to all the means of lives. Whereas, as an educational institution, Darussalam Modern Islamic Boarding School has to rely on its resources without having to be dependent on others for aid and assistance.

d) Islamic brotherhood in this regard is considered as the fourth fundamental principle of education to be implemented in this school through which every student learn how to build a strong friendship and empathetic solidarity upon the other Muslim brother. Happiness and sadness are shared under the banner of Islamic brotherhood, to actualize the unity of Muslim ummah.

e) Freedom is the fifth spirit to be imparted upon the heart of every student. This freedom makes Santri optimistic in facing the problem of life. It means freedom in thinking and act, also freedom in forming the future and choose the path of life, based on the Islamic faith and self-responsibility.

\subsection{The mottos of Gontor character education system}

The nature of character education in this pesantren mainly concerns with mental, personality, and character building of good Muslim. The personality of a good Muslim characterized in four points of qualities, good character, healthy body, extensive knowledge and freedom which are considered as the mottos of this pesantren education.

\footnotetext{
${ }^{2}$ In the view of KH Imam Zarkasyi, the word simplicity is not meant poverty, but to act in life according to the ability and basic need. This spirit of life implanted in the heart of every student through their daily life inside the campus within 24 hours. See, KH. Imam Zarkasyi dari Gontor merintis pondok modern, (1996) A biography of KH. Imam Zarkasyi, Ponorogo: Gontor Press, $1^{\text {st }}$ ed., p.60.
} 
a) Good character. The point of the unique character is considered as the principal character to be implemented by the school for all students, junior as well as senior all together. The realization of this motto is through the whole aspects of students lives on the campus.

b) Healthy body. The healthy body is one of the essential aspects of education in this school. With a healthy body, students can undertake their duties and responsibility as pleasant as possible. The school arranges some sports activities to maintain students' health. The sports program naturally carried out periodically.

c) Extensive knowledge. The students in this boarding school educated through the regular programs which can widen and enlarge their visions. The students are not only educated and taught some knowledge but also guided how to open the store of knowledge. The Kyai mostly frequently pursues that the world of knowledge is broad, not limited, but must be based on morality. Finally, they are conscious of the basic principle of learning.

d) Freedom of knowledge. This motto according to KH Abdullah Syukri Zarkasyi is not meant as liberalism ${ }^{3}$ [5]. The freedom of knowledge in this point should not go astray from the principle of being a true Muslim. However, symbolizes the thinking maturity based on the guidance of Allah. This point of the motto is implemented upon the students after having good character and broad knowledge.

\subsection{The philosopy of Gontor character education system}

Beside above motto, the philosophical statement and wise words often heard in many occasions, and often seen on the surface of the wall, pamphlets, written matters, to install good character in the personality of the students. Some the words are as follows: Dare to live not afraid to die; it would better die if afraid of life; Make the best life. Pondok Modern is above and for all groups. Pondok Modern is a place for devotion and not a place for earning a living. Give reward but do not claim the reward. The more to aware, the more to gain. Ready to lead and ready to be led, the new one will replace the old. The best human is the person who is beneficial to others. Do better than others do. Simplicity does not mean weak. Be the glue of the community. Other maxims like "Hidup sekali, hiduplah yang berarti" (Live once live meaningfully)," "The best man is one who is the most advantageous for others" are learned by heart [6].

About the philosophy of education of Gontor, KH Abdullah Syukri Zarkasyi said that a person could be educated not only through reading a text, but also by various activities of life ${ }^{4}$ [5]. Like the activities in relation with religious worships which teaches piety with all its dimensions indeed through the heart (bi al-qalbi), tongue (bi al-lisan), through reason (bi al'aql), and all parts of the body (bi-al-Jawarih ${ }^{5}$ [5]. When the process of learning in this instance undertaken naturally, the knowledge acquired by the student fully guided by Allah, and finally, he becomes intelligent to understand and undertake this life. Every human being has a

${ }^{3}$ ibid. p. 103 .

${ }^{4}$ Ibid. p. 22.

5 According to Allama Iqbal in his philosophy of the self, progressive perfection of every human being implies obstacles to be overcome. There are of two kinds, the physical obstacle presented by the outside environment, and the mental ones inherent in the personality of the self. The former is overcome by the mastery of nature through the discovery of its laws by the intellect, which faculty are evolved from experience and memory. Intellect extracts knowledge of the outer world from the indiscriminate stream of sense-perceptions. The mental obstacle to be overcome is our desires of the senses connected with that part of our personality which is a cumbersome heritage from the past. All these must be overcome by rigorous self-discipline and action based on moral and spiritual values. See M.Saeed Sheikh, (1972), Studies in Iqbal's Thought and Art; select articles from the Quarterly Iqbal, Lahore: Bazm-i-qbal, p. 70-71. 
potency to actualize his life in society. It is possible because man possesses some potencies consists of his physics, mind, and heart. A person in this instance, who wishes to actualize his potencies, needs different training, positive and right movements for physics, mind, and heart.

The actualization of this educational process must be started from self-consciousness upon the meaning of life as well as the meaningful life. ${ }^{6}$ In this institution students compelled to learn the philosophy of life, such as to live a meaningful life, once you live, be at a meaningful life, the life is meaningful when a person can serve other. So then, the more service a person gives to others in the religious and social life, the more meaningful he becomes, and the more worthful in the sight of his fellow being. The best person in this world is who gives meaning to others. In other word, give service but do not ask the other to serve.

The meaning behind that philosophy of life is that a person in this life should try to act for the advantage of the community. Naturally, they will judge his personality, and not asking others to justify his incompleted deed in life. From this philosophy of life, students of Gontor learn how to live in this world. The more conscious they become, the more advantages they get.

\section{Integrated university knowladge management in Universitas Darussalam Gontor}

\subsection{Integrated system on character education}

This fundamental principle of this character education consists of three dimensions of human potencies: physic, mind, and heart must be trained and explored entirely, and it is the original educational philosophy of Gontor system. ${ }^{7}$ To achieve the aim of education, UNIDA Gontor implemented a strategy of education, through the school campus with the whole totality become media of learning and education. Therefore, all school factors include Kiai, teachers, students and other school staffs, equipment, whether physical and nonphysical facilities constructed to support the educational milieu.

Based on this fact, the school environment purposely planned for the importance of education which based on community, consequently, the whole aspects which are heard, seen, felt, done, and undertaken by students inside the campus considered as media of learning and teaching and definitely become a device to achieve its aims and objectives. In this regard, Gontor

\footnotetext{
${ }^{6} \mathrm{Man}$ is the possessor of tremendous powers and immense potentialities. According to Iqbal human being has a relationship with the conception of space, time, and destiny as un-traversable barriers, and has thus given satisfactory basis to novelty, originality and initiative. No doubt, man is brought to the lowest of the low and is placed amidst an obstructing environment. But all this provides him with an opportunity to develop and assert his potentialities and powers. His imperfection becomes a necessary condition for his perfection. See, Allam Iqbal, The Reconstruction of Religious Thought in Islam, p. 12. See also Jamilah Khatoon, Iqbal's Perfect Man, Studies in Iqbal's Thought and Art, (1972), Lahore: Bazm-I -Iqbal), p. 131.

According to Abdur Rahman in his article on Iqbal's Philosophy of self, that the process of acquiring knowledge is a renewal of memory. We already had this knowledge in a previous existence; learning only refreshes our memory. But a more satisfactory explanation is that knowledge through the intellect is intuitional. And finally, our sense of moral values and spiritual significances is intuitional. That is to say, their knowledge comes spontaneously, as if from without, as a kind of inspiration. The intervention of intuition at each step, from simple sense-perception to the assessment of moral and spiritual values, clearly shows man's intimate connection with God. It is, therefore, clear that man's purpose is running parallel to God's purpose in working out his destiny. And fortunate is one whose purpose identifies itself with that of Allah. In Iqbal's view this is possible only by developing the self on religious lines, through intuition, helped by prayer, and propelled by love, See M.Saeed Sheikh, (1972), Studies in Iqbal's Thought and Art; select articles from the Quarterly Iqbal, Lahore: Bazm-i-qbal, p. 71-72.
} 
has a similar vision with the idea of learning society together with its four points of principle which formulated by UNESCO ${ }^{8}$ : learning to know, learning to do, learning to live together, and learning to be. Consequently, the University designs the character education system by integrating formal, informal and non-formal activities for the sake of building learner's character.

Formal. Three basics strategies design the formal education in this university, re-integrating Islam and sciences subjects, involving values and spirituality into teaching-learning process (the Islamization of sciences), and generating motto of teaching for lecturers.

The first design aims at integrating the Indonesian university national curriculum (KKNI) as the basic format and standard of the university curriculum with Islamic sciences subjects. The national curriculum considers the imparting of secular subjects as necessary to serve as a means to prepare school leavers and aid in the development of their professional future careers as engineers, doctors, economists, physicians, and social scientists [7]. However, Islamic studies subjects focusing on Al Quran and Islamic texts. Here, in this universe, the integration of both general sciences and Islamic sciences is wholly done. The primary purpose of this integration is to elevate and develop Indonesian people who devout and God-fearing, physically and mentally healthy, of stable personality, independent, has a deep sense of responsibility towards the society and the nation and possessed knowledge, skill and high morality. Providing a foundation for lifelong learning, character building, problem-solving and critical thinking, and developing the flexibility to manage change are vital factors for the curriculum reform [7]. Also, the language sciences in both Arabic and English are included as part of the integration such as interpretation sciences, Arabic and English grammars, language skills (speaking, reading, listening, and writing) [8].

The second design is considered as the significant effort on enriching moral education through a systematic insertion of Islamic values and codes of conduct both among the general and religious subjects. It can be portrayed as a viable alternative to the existing educational institutions in the sense that it provides formal education for the benefits of knowledge and, at the same time, an arena of instruction and mental training for students and the younger generation of Muslims to live by Islamic principles and values. It indicates how the curriculum is concerned not merely only in the development of students' core competency and skills, but also at nurturing their spiritual awareness and commitment. Finally, students should have sincere belief (salimu al-'aqidah) and piety (sahih al-'ibadah) before developing their maturity (matin al-khulq); independence (qadirun 'ala al-kasb); intelligence and knowledgeable (muthaqqaf alfikr); good health (qawiy al-Jism); seriousness and discipline (mujahidun li nafsih); correctness and accuracy (munadham fi shu'unih); efficiency (haarisun 'ala waqtih); and helpfulness (nafi'un li-ghairih to shape Muslim leadership [7].

The spirit and mottos for teachers in the teaching process are believed as the essential part of the education system in this university which is the third design of integrating education system. Its become the soul of the teaching process in this university. This method of teaching is "The method of teaching is more important than the subject, the teacher is more important than the method, the spirit of the teacher is the most important thing (in teaching-learning

\footnotetext{
${ }^{8}$ Teaching is of two kinds. One is conducted in words, expressions, lectures, books, etc., and is called instruction. The other deals with spiritual upbringing, character building, etc. and is called education. Generally speaking, one is related to letters and others with actions. But the tragedy is that in the contemporary era almost all over the world, instruction stands for education. Hence the aim of character building is universally neglected. This is why individuals without humaneness come out of instruction centres" miscalled" educational institution. See, Prof. Muhammad Munawwar, (1992), Iqbal Poet Philosopher of Islam, (Lahore: Iqbal Academy), $3^{\text {rd }}$. ed. P. 149.
} 
process)." The teachers are the key to learning and teaching in this integrated system. So, it is indispensable for them to have teaching competence and professionalism, intellectual capacity, moral integrity, high motivation, full of teaching spirit, knowledge and insights in Islam.

Informal. The basic principle of an integrated education system is installing religious values into student's minds not only in school times but also after these regular activities. These extracurricular activities are the way of imparting that values by creating or developing situation and condition for people to acquire, make a study and extend experiences and make alteration with the supporting social environment. The education atmosphere opens student possibilities to learn together and scaffold off one other by giving them the tools to act with complex social material for the sake of bridging the gap between life and school.

The university provides all kind of extramural activities for the student inside and outside the campus to enhance them potentially and socially. Students are given a chance to manage their selves in this campus with different activities which are education oriented programs. There are compulsory and elective activities (art and sport, personal building skills, religious programs). Both important programs are drawn up to make every learning accessible in the student's daily life.

The necessary activities which run by this university should be educationally adjusted and justified with the unique description. Students must undertake all of the obligated university programs for an academic reason. The university sets a particular role for this compulsory activity as the formal and academic requirements. The formal and academic activity will be fully accessed only when the necessary activities are met or comply with the minimum standard. The student grades will also be avowed when they achieve the standard. There are several essential programs in this university such as public speaking in Arabic and English, Jama'ah Prayer, Religious talk, campus disciplines, computer, language proficiency test, publication, and scientific research.

The other vital activities are the elective skills courses that train students skills regarded as necessary for them to effective, successful, and conscientious participation in the legal and nonlegal profession [9]. The following optional skills are sport and art skills such as football, basketball, tennis, badminton, bodybuilding, volleyball, table tennis, archery, gymnastics, martial art, music, drama, calligraphy, prophetic healing, and art design. The next courses are personal skills, for instance, sewing, handicraft, binding, electronic, computer, language courses, teaching practices, journalistic, shopkeeper, administration staff in several local offices. Finally, the religious courses also part of this elective skills, Jamiyatul Quro', fasting group, Tahajud group, a discussion group on Islamization of sciences, tutors discussion, tahfidz group, and discussion on Islamic studies.

Non-formal. Non-formal education is an addition or alternative learning in which some cases it can be structural but more flexible. It generally takes places in the workplace or communitybased milieu with the social activities settings. This non-formal education also considered as the educational activities that organized and established outside the formal system to serve identifiable learning clientless and learning objectives [10].

The Darussalam University system on non-formal education has drawn attention not only because of the environmental settings, but also it is system and training with the inculcation of values. The basis nonformal education in this university is Kiai or ulama as the central figure of education particularly in building the character. The Kiai (Rectors) play a fundamental role as the central figure for the students, moral force, leader, not a manager, and the teacher at the same time. The leader function leads Kiai to be part of the changes of the era, understanding the 
future challenges and finding every possible way to be part of global advancement. Furthermore, they as the teacher and moral force transmit knowledge and values inside and outside classrooms by active participation in planning, organizing, actuating, controlling, and evaluating student's activities.

The second principle of character education system in non-formal education in this university is enacting Masjid as the centre for activities. Historically, the centre of Islamic education was prayer places, mosques or the house of a scholar where students could sit on the floor facing their master and learn religious subjects. In the university mosque, the majority of character education programs are carried out by involving all of the university elements. The following programs are a daily speech from rectors and lecturers after Maghrib praying, Tahfidz Al Qur'an, discussion on Islamization of sciences and Dirasah Islamiyah, academic and nonacademic meeting, discussion on Turats, Tahsin, and Qiro'ah. These activities aim at building student awareness in Islamic character, and it is implemented in university life.

Also, students are lived inside the campus with full formal and informal activities that bound in the strict discipline as the method of character building. They have to live in the dormitories in which they manage their dormitories by themselves under teacher supervision. In this case, students and teachers are internally in 24 hours. It is widely known that rectors, lecturers, and students are living inside campus together. Consequently, direct interaction and communication between them occur in daily life. Rectors as the Kiai teach them the philosophy of Gontor's life theoretically and in real life.

All of the aspects of this university are designed for education where the traditional Pondok dictate campus life. Students are given all of those alternatives to find their inclination to realize the future. On the other hand, students are involved in all organization and management activities such as dormitory management, organizing the Gontor welfare centres, student guidance, student organization, management of Gontor's student, seminar, and workshop.

Finally, the spirit of Pondok dictates campus life for the sake of values inculcation. The five spirits, philosophy, and mottos of Pondok Gontor are implemented in all activities, the ulama or Kiai are responsible for reiterating Islamic value as the core of the character building process on all occasion. Being an Uswah is the mandatory requirement from all of the senior lecturers. 


\subsection{UNIDA Gontor: the fountain of wisdom}

From the previous data, it can be deduced that integrated Islamic Education of UNIDA Gontor system cannot be denied from its strong relationship with the existence of new boarding schools based education in Indonesia since this educational institution is naturally implementing the traditional Muslim pattern of education and Islamic school system. This school played a critical role in building up the Islamic character of the university level and prepared some numbers of intellectual and religious national leaders of the Muslim community.

The experience of UNIDA Gontor system in implementing the integrated Islamic education, with its unique curriculum, subject content, and method is an crucial point to be explored for the development of Islamic University education system in Indonesia. This school consistently exists as the centre of learning of Islamic knowledge and sciences since its establishment in 1926 up to now. ${ }^{9}$

The existence of UNIDA Gontor Islamic boarding school with the dynamic innovation of its system, according to Abdullah Syukri due to three essential school aspects. The first is school values; the second is a reliable system and the third is the subject content of boarding schoolbased education. The value as the first aspect of Gontor Islamic boarding school is an Islamic value consisted in its five spirits, indeed sincerity $^{10}$, modesty ${ }^{11}$, self-help ${ }^{12}$, Islamic brotherhood $^{13}$ And freedom ${ }^{14}$. This school spirit manifested in the whole school activities and dimensions as the basis of its integrated system of education.

The second aspect is a reliable system. The nature of this system is an integration of community-based education and school-based management, in the boarding system and controlled by strict discipline. This system is also can be said as the combination of home, society and school education. The home aspect in this regard is in the form of members of school guardians, teachers, and the students who live together and having a personal relationship as the members of a single family. Moreover, the school aspect is the academic lives in the campus;

\footnotetext{
${ }^{9}$ Abdullah Syukri Zarkasyi, (2005), Gontor dan pembaharuan pendidikan pondok, Jakarta: PT Raja Grafindo Persada, ed. 1, p. 87

${ }^{10}$. The word sincerity can be defined as a quality of being sincere, which means that every individual in this school must try to be sincere in all acts of devotion for the sake of Allah (worship) and not for reaping any profit from it. The teachers are sincere in doing the educational process, and the students are sincere in seeking the knowledge. The implementation of this spirit is through the whole aspects of lives inside the campus. Every school activity which can be seen, heard, and felt is considered as a mean of education. See, Abdullah Syukri Zarkasyi, (2005), ibid, p. 104.

${ }^{11}$ Modesty is meant as positive conduct towards every situation of life, and not surrender upon the problems of lives. The precise meaning of it is to procure for the individual's values that will prepare them to face the trials and tribulations. It is to have strength, courage, determination, and self-control. And behind these all, lies nobility, bravery and zeal never to give up, as well as the development of a strong mentality and character that are imperative and necessary in preparing them to face the hardship in life, ibid.

${ }^{12}$ Self-help is defined as standing on one's feet. It is the most important and effective ability provided by this school for its students. The students in this due regard practice by themselves how to be self-reliant in undertaking all his daily necessity, up to all the means of lives. Whereas, as an educational institution, Darussalam Islamic Boarding School has to rely on its resources without having to be dependent on others for aid and assistance, ibid.

${ }^{13}$ in this regard is considered as the fourth fundamental principle of education to be implemented in Gontor school through which every student learn how to build a strong friendship and empathetic solidarity upon the other Muslim brother. Happiness and sadness are shared under the banner of Islamic brotherhood, to actualize the unity of Muslim ummah, ibid, p. 105.

${ }^{14}$ Freedom is the fifth school spirit to be imparted upon the heart of every student. This freedom makes the pupil optimistic in facing the problem of lives. The meaning behind this word is freedom in thinking and acts, freedom in deciding the profession, freedom in forming his future and freedom in creativity of life based on the Islamic faith and principle, ibid.
} 
meanwhile, the social aspect is the totality of students, teachers, and guardians lives inside the campus as the members of the directed community.

This system actively supports the implementation of an integrated curriculum which can be controlled within twenty-four hours daily. The advantage of this system can be measured through three points; the first is effective coordination among the members of campus personnel, the second is an ability to control and construct the character of a student by utilizing all school facilities as the mean of education media. Moreover, the third point is the existence of the mosque as the central spiritual activities and the guardian as the symbol of an ideal life.

The third aspect of Gontor system to be concerned here is subject content. The subject taught in this system is an integration of revealed and acquired knowledge. Based on the philosophy of this school there is no dichotomy of science, both revealed and acquired derived from the single transcendental source. The second and the third aspects of boarding schoolbased education which applied by Gontor can be innovated with the development of the modern system, situation, and condition. Meanwhile, about the first aspect, indeed school values cannot be altered, due to its original and universal, which derived from the teaching of the holy alQur'Én and Prophetic Tradition.

\subsection{The methods of UNIDA Gontor system on character education}

The whole activities of character education in this boarding school are imparted upon the students through various methods, which can be deliberated in the following points:

a). A good example. In this regard, Kiai as the central religious figure tries to introduce upon the students the whole principle of school life. He acts in front of every individual how to be a perfect and sincere guardian. He shows in front of the student how to be a disciplined teacher, and finally, he must also give an example of how to be generous, to donate all his possession for the development of the school. So then everyone can imitate clearly. All elements of the school must practice the spirit of sincerity, include administrator, managers, students as well as the parents of the students.

b). Establishment conductive milieu. This boarding school conducts that the medium of education and teaching in this regard include the whole aspects of lives which can be seen, heard, felt and touched daily by the students inside the campus.

c). Guidance and counselling. The activities to be carried out by every individual in this school must be started from orientation, guidance and clear example, particularly in implementing the essential educational values.

d). Habituation, the school always uses the habitation method to impart educational values upon students. Through which the students in some cases compelled to do educational and instructional programs, which are too complicated to be carried out.

e). Responsibility for assignment. In this case, the students are taking action the various aspects of the educational process through the school assignments by organizing the student's activities, undertaking various responsibilities of the school economic enterprises out of personal interest, and doing some social services for the sake of humanitarian.

f). Discipline. The discipline is considered a spirit of activities in the school. This discipline is practised by Darussalam Gontor Modern Islamic Boarding school to introduce upon the students the reality of life in the community. The method is done by doing not by mouth. Some examples of school discipline in this regard are language discipline, class attendance discipline, sports discipline, dress discipline, examination discipline, shopping and so on.

g). Enthusiasm. In many occasions, Kyai always underlines the importance of having a high spirit in doing any work. It helps someone to get success in this life. The habitation in this 
due regard has been introduced since the beginning of studentship in this Modern Islamic Boarding School.

\section{References}

[1] A. Agboola and K. C. Tsai, "Bring Character Education into Classroom," Eur. J. Educ. Res., vol. 1, no. 2, pp. 163-170, 2012.

[2] M. W. Berkowitz and M. Schwartz, "Character Education," 2002.

[3] The Jubilee Centre for Character \& Values, "A Framework for Character Education in Schools," 2013.

[4] M. Davidson, T. Lickona, and V. Khmelkov, "Smart \& good schools: A new pardigm for high school character education," Handb. moral character Educ., pp. 370-390, 2008.

[5] I. Bahroni, "Streamlining Education Institution Through Waqf Enlargement: An Experience of Gontor System,” J. At-Ta'dib, vol. 7, no. 2, pp. 339-361, 2012.

[6] H. F. Zarkasyi, "TSAQAFAH Jurnal Peradaban Islam," Pondok Pesantren Di Yogyakarta, vol. 11, no. 2, pp. 223-248, 2015.

[7] I. Bahroni, "The Principle of Integrated Islamic Education," At-ta'dib, vol. 9, no. 1, pp. $1-22,2014$.

[8] A. Khuwaileh and A. Al Shoumali, Writing Errors: A Study of the Writing Ability of Arab Learners of Academic English and Arabic at University, vol. 13. 2000.

[9] R. Johnstone and S. Vignaendra, "LEARNING OUTCOMES AND CURRICULUM DEVELOPMENT IN LAW," Canberra, 2003.

[10] A. H. CHAUDHRY, "DEVELOPING A MODEL FOR STUDENT SUPPORT SERVICES AT AIOU,” Allama Iqbal Open University, 2008. 